\title{
Achievement and maintenance of the new impact factor 2010
}

\author{
P. Falkai • H.-J. Möller
}

(c) The Author(s) 2011. This article is published with open access at Springerlink.com

We are pleased to inform our readership and authors about an improved new impact factor for the European Archives of Psychiatry and Clinical Neuroscience in 2010. The journal managed raising its impact factor from 2.747 to 3.637 and herewith achieving the best result in the history of EAPCN. Hereby, our journal's position ascends from position 59 to 40 in the ranking of Clinical Neurological journals and from 47 to 31 in the ranking of Psychiatric journals. We would like to thank all our authors and reviewers for their valuable contributions, allowing such an increase in quality. Further reasons for the rise of our impact factor probably are based upon the high quality of reviewers as leading experts in their fields and the focus on original manuscripts with topics related to neurobiological key aspects. 2008 and 2009, the years determining the 2010 impact factor, are characterized by frequent citations in several issues. Some examples of well-cited manuscripts referring to genetic backgrounds of psychiatric diseases are e.g., Maier et al. [1], Kishi et al. [2], and Gonda et al. [3], for genetic imaging Kircher et al. [4] gained remarkable attention, likewise D'Souza et al. [5] for effects of environmental factors and Koenen et al. [6] and Grisham et al. [7] for gene-environment interactions. Of substantiated scientific interest obviously are well-cited studies on psychopharmacological treatment options and their relationship to neurobiology (Möller et al. [8], Möller [9, 10],

P. Falkai $(\bowtie)$

Department of Psychiatry and Psychotherapy,

University of Göttingen, Von-Siebold-Str. 5,

37075 Göttingen, Germany

e-mail: pfalkai@gwdg.de

H.-J. Möller

Psychiatry Hospital, Ludwigs-Maximilians-University Munich, Nussbaumstr.7, 80336 Munich, Germany
Leyhe et al. [11], Bauer et al. [12], Mendes et al. [13], Rösler et al. [14]). This also applies to the neurobiological background of psychiatric diseases, including brain imaging, molecular, proteomic, and biochemical studies (Müller and Schwarz [15], Scherk et al. [16], Martins-de-Souza et al. [17], Galve-Roperh et al. [18], Zanetti et al. [19], Hoeppner et al. [20]).

This success highly motivates our EAPCN team to maintain a platform for neuropsychiatric publications comprising high class methodology in the European catchment area. Respectively, our future issues will focus on multifaceted neurobiological aspects and original work, while we intend to refrain from publishing case reports and pure validations of psychiatric rating scales. In accordance to this policy, in the September issue, we set our focus on perinatal complications and their interaction with genetic factors in a sibling design in anorexia nervosa by Favaro et al. [21] as well as lifetime cannabis use as a predictor of earlier age of onset in bipolar disorder by Lagerberg et al. [22]. These studies extend our knowledge on environmental factors and gene-environment interactions in major psychiatric diseases. In addition, in a voxel-based morphometric study, Molina et al. [23] rely on brain morphological correlates of atypical antipsychotics and find several brain regions related to clinical improvement or non-response. The paper confirms previous investigations in which striatal size has been referred to action of antipsychotics and extends the knowledge to other brain regions such as insular cortex. A further study of Correll et al. [24] on aspects of side effects of second generation antipsychotics in patients without metabolic syndrome addresses aspects of obesity as a frequent adverse effect of treatment. To complete the complex picture of treatment strategies, one study of Kristensen et al. [25] focuses on electroconvulsive therapy in treatment-refractory 
schizophrenia. In an interesting FDG-PET study of Poljanski et al. [26] in a large cohort of patients with frontotemporal lobar degeneration compared to patients with Alzheimer's disease or mild cognitive impairment, a sensitivity of FDG-PET of $89 \%$ could be reached for correct diagnosis of patients with frontotemporal lobar degeneration. Cognitive impairments are central symptoms in psychiatric patients, often leading to social deficits and burden of the disease. Using a neuropsychological test battery in a population-based sample of patients with major psychiatric diseases, Tuulio-Henriksson et al. [27] found mainly patients with schizophrenia and non-affective psychoses impaired, suggesting that with respect to this domain, these patients are more severely affected than patients with affective disorders.

We hope that these aspects are of interest for our readership and are looking forward receiving further likewise interesting manuscripts in 2011.

Open Access This article is distributed under the terms of the Creative Commons Attribution Noncommercial License which permits any noncommercial use, distribution, and reproduction in any medium, provided the original author(s) and source are credited.

\section{References}

1. Maier W, Zobel A (2008) Contribution of allelic variants to the phenotype of response to antidepressants and antipsychotics. Eur Arch Psychiatry Clin Neurosci 258(Suppl 1):12-20

2. Kishi T, kitajima T, Ikeda M, Yamanouchi Y, Kinoshita Y, Kawashima K, Okochi T, Okumura T, Tsunoka T, Inad T, Ozaki N, Iwata N (2009) Association study of clock gene (CLOCK) and schizophrenia and mood disorders in the Japanese population. Eur Arch Psychiatry Clin Neurosci 259:293-297

3. Gonda X, Fountoulakis KN, Juhasz G, Rihmer Z, Lazary J, Laszik A, Akiskal HS, Bagdy G (2009) Association of the s allele of the 5-HTTLPR with neuroticism-related traits and temperaments in a psychiatrically healthy population. Eur Arch Psychiatry Clin Neurosci 259(2):106-113

4. Kircher T, Thienel R, Wagner M, Habel U, Kellermann T, Frommann I, Schwab S, Wölwer W, von Wilmsdorff M, Braus DF, Schmitt A, Rapp A, Stöcker T, Shah NJ, Henn FA, Sauer H, Gaebel W, Maier W, Schneider F (2009) Neurgeulin 1 ICE-single nucleotide polymorphism in first episode schizophrenia correlates with cerebral activation in fronto-temporal areas. Eur Arch Psychiatry Clin Neurosci 259:72-79

5. D'Souza DC, Sewell RA, Ranganathan M (2009) Cannabis and psychosis/schizophrenia: human studies. Eur Arch Psychiatry Clin Neurosci 259(7):413-431

6. Koenen KC, Nugent NR, Amstadter AB (2008) Gene-environment interaction in posttraumatic stress disorder: review, strategy and new directions for future research. Eur Arch Psychiatry Clin Neurosci 258(2):82-96

7. Grisham JR, Anderson TM, Sachdev PS (2008) Genetic and environmental influences on obsessive-compulsive disorder. Eur Arch Psychiatry Clin Neurosci 258(2):107-116

8. Möller HJ, Baldwin DS, Goodwin G, Kasper S, Okasha A, Stein DJ, Tandon R, Versiani M, WPA Section on Pharmacopsychiatry (2008) Do SSRIs or antidepressants in general increase suicidality? WPA section on pharmacopsychiatry: consensus statement. Eur Arch Psychiatry Clin Neurosci 258(Suppl 3):3-23

9. Möller HJ (2008) Do effectiveness ("real world" studies on antipsychotics tell us the real truth? Eur Arch Psychiatry Clin Neurosci 258(5):257-270

10. Möller HJ (2008) Isn't the efficacy of antidepressants clinically relevant? A critical comment on the results of the metaanalysis by Kirsch et al. (2008). Eur Arch Psychiatry Clin Neurosci 258(8): 451-455

11. Leyhe T, Stransky E, Eschweiler GW, Buchkremer G, Laske C (2008) Increase of BDNF serum concentration during donepezil treatment of patients with early Alzheimer's disease. Eur Arch Psychiatry Clin Neurosci 258(2):124-128

12. Bauer M, Tharmanathan P, Volz HP, Möller HJ, Freemantle N (2009) The effect of venlafaxine compared with other antidepressants and placebo in the treatment of major depression: a meta-analysis. Eur Arch Psychiatry Clin Neurosci 259(3): 172-185

13. Mendes CT, Mury FB, de Sa Moreira E, Alberto FL, Forlenza OV, Dias-Neto E, Gattaz WF (2009) Lithium reduces Gsk3b mRNA levels: implications for Alzheimer disease. Eur Arch Psychiatry Clin Neurosci 259(1):16-22

14. Rösler M, Fischer R, Ammer R, Ose C, Retz W (2009) A randomized, placebo-controlled, 24-week, study of low-dose extended-release methylphenidate in adults with attention-deficit/ hyperactivity disorder. Eur Arch Psychiatry Clin Neurosci 259(2): $120-129$

15. Müller N, Schwarz MJ (2008) A psychoneuroimmunological perspective to Emil Kreapelins dichotomy: schizophrenia and major depression as inflammatory CNS disorders. Eur Arch Psychiatry Clin Neurosci 258(Suppl 2):97-106

16. Scherk H, Kemmer C, Usher J, Reith W, Falkai P, Gruber O (2008) No change to grey and white matter volumes in bipolar I disorder patients. Eur Arch Psychiatry Clin Neurosci 258(6): 345-349

17. Martins-de-Souza D, Gattaz WF, Schmitt A, Rewerts C, Maccarone G, Dias-Neto E, Turck CW (2009) Prefrontal cortex shotgun proteome analysis reveals altered calcium homeostasis and immune system imbalance in schizophrenia. Eur Arch Psychiatry Clin Neurosci 259:151-163

18. Galve-Roperh I, Palazuelos J, Aguado T, Guzman M (2009) The endocannabinoid system and the regulation of neual development: potential implications in psychiatric disorders. Eur Arch Psychiatry Clin Neurosci 259(7):371-382

19. Zanetti MV, Jackowski MP, Versace A, Almeida JR, Hassel S, Duran FL, Busatto GF, Kupfer DJ, Phillips ML (2009) Statedependent microstructural white matter changes in bipolar I depression. Eur Arch Psychiatry Clin Neurosci 259(6):316-328

20. Höppner J, Prudente-Morrissey L, Herpertz SC, Benecke R, Walter U (2009) Substantia nigra hyperechogenicity in depressive subjects relates to motor asymmetry and impaired word fluency. Eur Arch Psychiatry Clin Neurosci 259(2):92-97

21. Favaro A, Tenconi E, Bosello R, Degortes D, Santonastaso P (2011) Perinatal complications in unaffected sisters of anorexia nervosa patients: testing a covariation model between genetic and environmental factors. Eur Arch Psychiatry Clin Neurosci 260(6). doi:10.1007/s00406-010-0181-3

22. Lagerberg TV, Sundet K, Aminoff SR, Berg AO, Ringen PA, Andreassen OA, Melle I (2011) Excessive cannabis use is associated with earlier age at onset in bipolar disorder. Eur Arch Psychiatry Clin Neurosci 260(6). doi:10.1007/s00406-011-0188-4

23. Molina V, Martin C, Ballestros A, Seco de Herrera AG, Hernandez-Tamames JA (2011) Optimized voxel brain morphometry: association between brain volumes and the response to atypical antipsychotics. Eur Arch Psychiatry Clin Neurosci 260(6). doi:10.1007/s00406-010-0182-2 
24. Correll CU, Kane JM, Manu P (2011) Obesity and coronary risk in patients treated with second-generation antipsychotics. Eur Arch Psychiatry Clin Neurosci 260 (6). doi:10.1007/s00406010-0177-z

25. Kristensen D, bauer J, Hageman I, Jorgensen MB (2011) Electroconvulsive therapy for treating schizophrenia: a chart review of patients from two catchment areas. Eur Arch Psychiatry Clin Neurosci 260(6). doi:10.1007/s00406-010-0173-3

26. Poljansky S, Ibach B, Hirschberger B, Männer P, Klünemann H, Hajak G, Marienhagen J (2011) A visual [18F]FDG-PET rating scale for the differential diagnosis of frontotemporal lobar degeneration. Eur Arch Psychiatry Clin Neurosci 260(6). doi: 10.1007/s00406-010-0184-0

27. Tuulio-Henriksson A, Perälä J, Saarni SI, Isometsä E, Koskinen S, Lönnqvist J, Suvisaari J (2011) Cognitive functioning in severe psychiatric disorders: a general population study. Eur Arch Psychiatry Clin Neurosci 260(6). doi:10.1007/s00406-010-0186-y 